\title{
ASSESSMENT OF COVID-19 CLINICAL COURSE IN PATIENTS VACCINATED WITH SPITNIK V, SARS-COV-2 S PROTEIN RBD DOMAIN VARIATION AND SERUM VIRUS NEUTRALIZING ACTIVITY
}

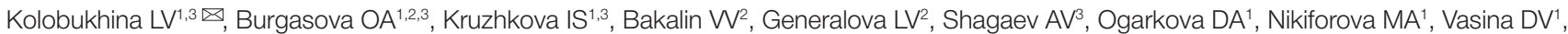
Gushchin VA ${ }^{1,4}$, Smetanina SV ${ }^{3}$

${ }^{1}$ Gamaleya National Center of Epidemiology and Microbiology, Moscow, Russia

2 Peoples' Friendship University of Russia, Moscow, Russia

${ }^{3}$ Infectious Clinical Hospital № 1, Moscow, Russia

${ }^{4}$ Lomonosov Moscow State University, Moscow, Russia

The COVID-19-associated mortality remains high. Studying the features of the COVID-19 course in vaccinated patients, who have got ill on different dates after vaccination, compared to unvaccinated individuals is relevant. The study was aimed to assess clinical and immunological features of the COVID-19 course, as well as to assess humoral immunity (virus neutralizing activity, VNA) and SARS-CoV-2 S protein RBD domain variation in the groups of patients, previously vaccinated with Sputnik V, and unvaccinated patients. A total of 251 patients with confirmed diagnosis of COVID-19 were enrolled, of them 116 individuals were previously vaccinated with one or two Sputnik V vaccine components, and 135 patients were not vaccinated (comparison group). Individuals over 50 years of age prevailed (82.8\%). The patients, who received two vaccine components, had mild to moderate COVID-19 (92.1\%). In the group of unvaccinated patients, 11 individuals received treatment in the ICU, 10 of them died. The viral load was significantly lower in vaccinated patients. Mutations of SARS-CoV-2, such as S477N, S477N+A522S, E484K and E484K+S494P, were identified both in vaccinated and unvaccinated patients. Assessment of the neutralizing activity of sera revealed no significant differences in VNA against different variants of SARS-CoV-2 mutations. The data obtained demonstrate that the lack of vaccination is an aggravating factor and is capable of increasing the risk of severe course and death in patients with COVID-19. Keywords: vaccine, Sputnik V, vaccination, COVID-19, patients

Acknowlegments: we would like to thank Antipyat NA, Deputy Chief Physician for Medical Affairs, and Bazarova MV, PhD, Deputy Chief Physician for Sanitary and Epidemiological Issues, Infectious Clinical Hospital № 1, for the study management and support.

Author contributions: Kolobukhina LV — study proponent, design, manuscript writing, clinical research management; Burgasova OA — literature analysis, manuscript writing and editing, clinical research data processing; Kruzhkova IS — clinical observation, literature analysis, processing of the results; Bakalin W - clinical observation, clinical and laboratory data processing; Generalova LV — clinical data processing; Shagaev AV — monitoring of infected individuals after vaccination; Ogarkova DA statistical analysis; Nikiforova MA — coordination of virological studies, virus isolation and VNA; Vasina DV — ELISA data processing, coordination of immunological studies; Gushchin VA — study concept, molecular biological and virological research management; Smetanina SV — clinical research general management.

Compliance with ethical standards: the study was approved by the Ethics Committee of Moscow Infectious Clinical Hospital (protocol № 11/A dated November 16, 2020). The informed consent was submitted by all patients.

$\triangle$ Correspondence should be addressed: Ludmila V. Kolobukhina

Gamaleya St. 18, Moscow, 123098, Russia; Ikolobuchina@yandex.ru

Received: 29.09.2021 Accepted: 13.10.2021 Published online: 17.10.2021

DOI: $10.24075 /$ brsmu.2021.046

\section{ОЦЕНКА КЛИНИЧЕСКОГО ТЕЧЕНИЯ COVID-19 У ПАЦИЕНТОВ, ВАКЦИНИРОВАННЫХ “СПУТНИК V», ИЗМЕНЧИВОСТИ RBD-ДОМЕНА S-БЕЛКА SARS-COV-2 И ВИРУСНЕЙТРАЛИЗУЮЩИХ СВОЙСТВ СЫВОРОТКИ}

Л. В. Колобухина ${ }^{1,3} \unrhd$, О. А. Бургасова ${ }^{1,2,3}$, И. С. Кружкова ${ }^{1,3}$, В. В. Бакалин ${ }^{2}$, л. В. Генералова², А. В. Шагаев ${ }^{3}$, Д. А. Огаркова

М. А. Никифорова', Д. В. Васина', В. А. Гущин ${ }^{1,4}$, С. В. Сметанина ${ }^{3}$

Национальный исследовательский центр эпидемиологии и микробиологии имени Н. Ф. Гамалеи, Москва, Россия

2 Российский университет дружбы народов, Москва, Россия

${ }^{3}$ Инфекционная клиническая больница № 1, Москва, Россия

${ }^{4}$ Московский государственный университет имени М. В. Ломоносова, Москва, Россия

Показатель смертности от COVID-19 сохраняется достаточно высоким. Актуально изучение особенностей течения COVID-19 у вакцинированных пациентов, заболевших в разные сроки после прививки, по сравнению с невакцинированными. Целью работы было оценить клинико-иммунологические особенности течения COVID-19, проанализировать данные гуморального иммунитета (вируснейтрализующей активности, BHA) и изменчивости RBDдомена S-белка SARS-CoV-2 в группах пациентов, ранее вакцинированных “Спутником V», и у невакцинированных. В исследование включили 251 пациента с верисицированным диагнозом COVID-19, из них 116 были ранее вакцинированы одним или двумя компонентами препарата «Спутник V» и 135 невакцинированных (группа сравнения). Преобладали лица старше 50 лет (82,8\%). Пациенты, получившие оба компонента вакцины, перенесли COVID-19 в легкой и среднетяжелой форме (92,1\%). В группе невакцинированных пациентов 11 человек лечили в условиях ОРИТ, 10 из них умерли. Вирусная нагрузка была достоверно ниже у вакцинированных пациентов. Мутации SARS-CoV-2, включая S477N, S477N+A522S, E484K и E484K+S494P, были выявлены у пациентов как вакцинированных, так и невакцинированных. По результатам анализа нейтрализующей активности сывороток не обнаружена достоверная разница уровня BHA против различных вариантов мутаций SARS-CoV-2. Полученные данные свидетельствуют, что отсутствие вакцинации является отягчающим фактором и увеличивает риск тяжелого течения и смерти пациентов с COVID-19.

Ключевые слова: вакцина, «Спутник V», вакцинация, COVID-19, пациенты

Благодарности: заместителю главного врача по медицинской части ИКБ № 1 Н. А. Антипят и заместителю главного врача по санитарноэпидемиологическим вопросам ИКБ № 1 М. В. Базаровой - за организацию и поддержку процесса исследования.

Вклад авторов: Л. В. Колобухина - инициатор исследования, дизайн, подготовка рукописи, руководство клинической частью; О. А. Бургасова — анализ источников, подготовка и правка статьи, обработка результатов клинической части; И. С. Кружкова - клинические наблюдения, анализ источников, обработка результатов; В. В. Бакалин — клинические наблюдения, обработка клинических и лабораторных данных; Л. В. Генералова — обработка клинических данных; А. В. Шагаев - мониторинг заболевших лиц после вакцинации; Д. А. Огаркова - статистический анализ; М. А. Никифорова - координация вирусологических исследований, выделение вируса и ВНА; Д. В. Васина - обработка данных ИФА, координация иммунологической части исследования; В. А. Гущин - концепция исследования, руководство молекулярно-биологическим и вирусологическим направлениями исследований; С. В. Сметанина общее руководство клинической частью исследования.

Соблюдение этических стандартов: исследование одобрено этическим комитетом Инфекционной клинической больницы № 1 г. Москвы (протокол № 11/А от 16 ноября 2020 г.). Все пациенты подписали добровольное информированное согласие.

$\bowtie$ Для корреспонденции: Людмила Васильевна Колобухина

ул. Гамалеи, д. 18, г. Москва, 123098, Россия; Ikolobuchina@yandex.ru

Статья получена: 29.09.2021 Статья принята к печати: 13.10.2021 Опубликована онлайн: 17.10.2021

DOI: $10.24075 /$ vrgmu.2021.046 
The COVID-19 pandemic, declared by the World Health Organization in 2020, swept across the world. In the majority of cases (80\%), COVID-19 is subclinical, and the patients do not require hospitalization. Many factors associated with severe course of the disease are well understood, however, the COVID-19-associated mortality remains rather high, especially in unvaccinated individuals of the older age groups [1].

The history of medicine demonstrates that the pandemic can be stopped by successful vaccination and reaching the herd immunity threshold of at least $70-80 \%$. Furthermore, vaccination reduces the risk of severe disease and death [2].

To date, credible levels of protection against the infection (over 90\%) and severe course have been achieved for all the vaccines against COVID-19 [3]. In the countries, being the leaders of the universal immunization programme, a downward trend in morbidity and mortality is observed [4]. Official statistics indicates the decrease in COVID-19-associated morbidity and mortality in the countries, being the leaders in terms of vaccination coverage (50 vaccine doses per 100 individuals), such as Israel, United Arab Emirates, USA and United Kingdom [5].

The results of assessing the vaccine efficacy within the framework of post-registration trials confirm the results of clinical trials on vaccine safety and efficacy $[6,7]$.

Sputnik $V$ vaccine, providing high neutralizing antibody titers and substantial cellular immune response, has been developed, tested and put into practice in the Russian Federation (RF) [8]. The vaccine mechanism of action is based on the use of two adenovirus serotype Ad26 and Ad5 vectors, which are unable to replicate in the human body, but are capable of delivering the gene, encoding the SARS-CoV-2 S glycoprotein. According to the results of the phase III clinical trials conducted in Russia, Sputnik V vaccine efficacy was $91.6 \%$ [3]. However, clinical practice in many countries around the world confirm the risk of COVID-19 infection even after vaccination with two vaccine components [9]. The importance of this issue and the need for monitoring the COVID-19 cases in the population of vaccinated individuals emphasize the existence of the SARS-CoV-2 virus mutations, their potential clinical significance, and the risk of emerging new strains, which could potentially evade the immune response.

The study was aimed to assess the features of the COVID-19 clinical course in the groups of patients, previously vaccinated with Sputnik V, compared to unvaccinated patients.

\section{METHODS}

\section{Patients}

A total of 251 patients with confirmed novel coronavirus infection were enrolled. Inclusion criteria: RNA of SARS-CoV-2, detected by PCR. Exclusion criteria: no SARS-CoV-2 RNA in biological material.

In order to assess the features of COVID-19 clinical course in patients, previously vaccinated with Sputnik V, the patients who were staying in the Infectious Clinical Hospital No. 1 were December 2020 to April 2021 were randomized into two groups $(n=251)$. Of them 116 patients were admitted to hospital on various dates after vaccination with Sputnik V; the comparison group was represented by 135 unvaccinated patients. The disease severity was assessed using the NEWS scale [10] on the day of admission and on the day of enrollment (bed-days).

The group of vaccinated patients was divided into three subgroups based on the dates of vaccine component administration and the date of the disease onset. A total of 46 individuals, who got ill on days 1-7 after the first vaccine component administration, were included in the first subgroup; the second subgroup included 32 patients, who got ill on days 8-14 after the first vaccine component administration. The third subgroup included 38 patients, who got ill on days 1-132 after administration of two Sputnik $V$ vaccine components. There were 121 males (48.3\%) and 130 females (51.7\%) (Table 1). Persons over the age of 50 prevailed (82.8\%; $n=208)$, individuals aged $30-50$ accounted for $17.1 \%(n=43)$ of patients.

The algorithm for etiological confirmation of COVID-19 involved testing the nasal swab for SARS-CoV-2 RNA by PCR, assessing blood serum to detect the antibodies against SARSCoV-2 by ELISA, and identifying the protective antibodies by neutralization assay.

\section{Viral load determination method}

Nasopharyngeal swab samples were assessed using the reagent kit for SARS-CoV-2 coronavirus RNA extraction and qualitative analysis by RT-PCR, SARS-CoV-2 FRT (Gamaleya National Center of Epidemiology and Microbiology; Russia). Laboratory differential diagnosis of COVID-19 and other respiratory infections was performed by RT-PCR.

The relative quantities of SARS-CoV-2 RNA were defined using the calibration line, plotted for each analysis by the calibration standards testing. The latter were represented by recombinant constructs, containing the known concentration of the SARS-CoV-2 genome fragment to be amplified. Since the relative quantities of the fragments were compared, no RNA fragments were used. The step of reverse transcription was controlled by PCR passage through the internal control RNA provided by the system.

RNA/DNA of influenza viruses and viruses, causing $A R V I$, were identified using the AmpliSens Influenza viruses A/B, AmpliSens Influenza virus A/H1-swine-FL, AmpliSens Influenza virus A-type-FL, AmpliSens ARVI-screen-FL reagent kits (Central Research Institute of Epidemiology; Russia) in accordance with the manufacturer's guidelines using the PCR systems, working in the real-time mode: Rotor Gene 6000 (Corbett Research; Australia) and DT-96 (DNA-Technology; Russia).

\section{Quantification of IgG against SARS-CoV-2 RBD}

The recombinant RBD antigen No. 8COV1 (HyTest; Russia) was used for assessment of lgG antibodies against the SARSCoV-2 spike protein S1 receptor-binding domain (RBD). We added $100 \mu \mathrm{L}$ of RBD in phosphate buffered saline PBS (Amresco; USA) with a concentration of $1 \mu \mathrm{g} / \mathrm{mL}$ to each well of the 96-well ELISA microplate Costar High Binding (Corning; USA) and subsequently incubated the microplates for 24 hours at $+4 \mathrm{C}^{\circ}$. On the next day we removed the antigen solution and blocked the microplates overnight at $+4 \mathrm{C}^{\circ}$ by incubation with the blocking buffer S002X (Xema; Russia), containing 0.5\% casein.

The studied sera were diluted $1: 100$ with the ELISA buffer S011 (Xema; Russia), $100 \mu \mathrm{L}$ were added to each well and incubated for $1 \mathrm{~h}$ in the thermo-shaker at a temperature of +37 ${ }^{\circ} \mathrm{C}$ in the $600 \mathrm{rpm}$ mixing mode. Then the microplates were washed three times with PBS, containing $0.1 \%$ Tween 20, and $100 \mu \mathrm{L}$ of the goat anti-human IgG horseradish peroxidaseconjugated antibody (Novex; USA) diluted at a ratio of 1 : 40,000 were added to each well. After an hour of incubation at a temperature of $+37^{\circ} \mathrm{C}$ and mixing in the $600 \mathrm{rpm}$ mode, the microplates were washed six times. We added $100 \mu \mathrm{L}$ of 
Table 1. General characteristics of patients

\begin{tabular}{|c|c|c|c|c|c|c|}
\hline \multirow{5}{*}{ Parameters } & \multicolumn{5}{|c|}{ Total number of patiets $n=251$} & \\
\hline & \multirow{4}{*}{$\begin{array}{l}\text { Unvaccinated } \\
\qquad n=135\end{array}$} & \multicolumn{4}{|c|}{ Vaccinated } & \\
\hline & & $\begin{array}{c}\text { Subgroup } 1 \\
n=46\end{array}$ & $\begin{array}{c}\text { Subgroup } 2 \\
n=32\end{array}$ & \multicolumn{2}{|c|}{$\begin{array}{c}\text { Subgroup } 3 \\
n=38\end{array}$} & \\
\hline & & \multicolumn{4}{|c|}{ Dates of disease onset after vaccination } & \\
\hline & & 1-7 days after $\mathrm{V} 1$ & 8-14 days after $\mathrm{V} 1$ & \multicolumn{2}{|c|}{$1-132$ days after $\mathrm{V} 1+\mathrm{V} 2$} & \\
\hline Males & $\begin{array}{c}61 \\
(45.20 \%)\end{array}$ & $\begin{array}{c}29 \\
(63.0 \%)\end{array}$ & $\begin{array}{c}10 \\
(31.3 \%)\end{array}$ & \multicolumn{2}{|c|}{$\begin{array}{c}21 \\
(55.3 \%)\end{array}$} & \multirow{2}{*}{$\begin{array}{c}0.039^{*} \\
\text { (Pearson's } \chi^{2} \\
\text { test) }\end{array}$} \\
\hline Females & $\begin{array}{c}74 \\
(54.80 \%)\end{array}$ & $\begin{array}{c}17 \\
(37.0 \%)\end{array}$ & $\begin{array}{c}22 \\
(68.8 \%)\end{array}$ & \multicolumn{2}{|c|}{$\begin{array}{c}17 \\
(44.7 \%)\end{array}$} & \\
\hline Male to female ratio & $01: 01.0$ & $01: 01.0$ & $01: 02.0$ & \multicolumn{2}{|c|}{$01: 01.0$} & \\
\hline $\begin{array}{l}\text { Average age (years) } \\
\mathrm{M} \pm \mathrm{SE} \text { (min-max) }\end{array}$ & $\begin{array}{c}64.9 \pm 1.2 \\
(30-89)\end{array}$ & $64.5 \pm 2.1(31-84)$ & $68.9 \pm 2.1(46-89)$ & \multicolumn{2}{|c|}{$67.7 \pm 1.9(37-90)$} & $\begin{array}{l}0.335 \\
\text { (Pearson's } \\
\text { F-test) }\end{array}$ \\
\hline $\begin{array}{l}\text { Age. years } \\
30-50\end{array}$ & $\begin{array}{c}28 \\
(20.7 \%)\end{array}$ & $\begin{array}{c}8 \\
(17.4 \%)\end{array}$ & $\begin{array}{c}3 \\
(9.4 \%)\end{array}$ & \multicolumn{2}{|c|}{$\begin{array}{c}4 \\
(10.5 \%)\end{array}$} & \\
\hline $51-70$ & $\begin{array}{c}54 \\
(40.00 \%)\end{array}$ & $\begin{array}{c}20 \\
(43.5 \%)\end{array}$ & $\begin{array}{c}16 \\
(50.0 \%)\end{array}$ & \multicolumn{2}{|c|}{$\begin{array}{c}19 \\
(50.0 \%)\end{array}$} & $\begin{array}{c}0.656 \\
\text { (Pearson's } \chi^{2} \\
\text { test) }\end{array}$ \\
\hline $71-90$ & $\begin{array}{c}53 \\
(39.30 \%)\end{array}$ & $\begin{array}{c}18 \\
(39.1 \%)\end{array}$ & $\begin{array}{c}13 \\
(40.6 \%)\end{array}$ & \multicolumn{2}{|c|}{$\begin{array}{c}15 \\
(39.5 \%)\end{array}$} & \\
\hline \multirow{3}{*}{$\begin{array}{l}\text { Dates of admission to hospital. days } \\
\qquad M \pm S E \text { (min-max). Me }\left[Q_{1}-Q_{3}\right]\end{array}$} & \multirow{3}{*}{$\begin{array}{c}6.22 \pm 0.20 \\
(1-13) \\
6[5-8]\end{array}$} & $7.5 \pm 0.5(2-19)$ & $6.5 \pm 0.4(2-13)$ & \multirow{2}{*}{\multicolumn{2}{|c|}{$\begin{array}{c}8.3 \pm 0.8(1-28) \\
7[6-10]\end{array}$}} & \multirow{3}{*}{$\begin{array}{l}0.014^{*} \\
\text { (Mann- } \\
\text { Whitney U } \\
\text { Test) }\end{array}$} \\
\hline & & $7.5[4-9]$ & $6.5[5-8]$ & & & \\
\hline & & \multicolumn{4}{|c|}{$\begin{array}{c}7.5 \pm 0.4(1-28) \\
7[5-9]\end{array}$} & \\
\hline \multicolumn{7}{|c|}{ Disease severity evaluation upon admission to hospital } \\
\hline \multirow[t]{2}{*}{ Mild } & \multirow{2}{*}{$\begin{array}{c}52 \\
(38.50 \%)\end{array}$} & $\begin{array}{c}17 \\
(36.90 \%) \\
\end{array}$ & $\begin{array}{c}13 \\
(40.60 \%) \\
\end{array}$ & \multirow[t]{2}{*}{$\begin{array}{c}19 \\
(50.0 \%)\end{array}$} & \multirow{6}{*}{\multicolumn{2}{|c|}{0.498 (Pearson's $\chi^{2}$ test) }} \\
\hline & & & $49(42.2 \%)$ & & & \\
\hline Moderate & 35 & $\begin{array}{c}16 \\
(34.8 \%)\end{array}$ & $\begin{array}{c}9 \\
(28.10 \%) \\
\end{array}$ & $\begin{array}{c}9 \\
(23.70 \%) \\
\end{array}$ & & \\
\hline & & & $34(29.3 \%)$ & & & \\
\hline \multirow[t]{2}{*}{ Severe } & \multirow[t]{2}{*}{$\begin{array}{c}48 \\
(35.50 \%)\end{array}$} & $\begin{array}{c}13 \\
(28.3 \%)\end{array}$ & $\begin{array}{c}10 \\
(31.30 \%)\end{array}$ & $\begin{array}{c}10 \\
(26.3 \%)\end{array}$ & & \\
\hline & & \multicolumn{3}{|c|}{$33(28.4 \%)$} & & \\
\hline Of them transferred to ICU & 11 & 2 & 2 & 0 & & \\
\hline Deaths in ICU & 10 & 2 & 0 & 0 & & \\
\hline \multirow{3}{*}{$\begin{array}{l}\text { Length of hospital stay (days) } \\
\text { depending on severity: } \\
M \pm \text { SE (min-max). Me }\left[Q_{1}-Q_{3}\right]\end{array}$} & & $10.35 \pm 0.8(4-36)$ & $9.0 \pm 1.5(2-53)$ & $\begin{array}{c}8.03 \pm 0.4 \\
(4-14)\end{array}$ & & \\
\hline & $11.12 \pm 0.6(4-52)$ & $8[7-12]$ & $8[6.5-9]$ & 8 [7-9] & Mann-V & 001* \\
\hline & & & $\begin{array}{c}22 \pm 0.5(2-53) \\
8[7-9.5]\end{array}$ & & & \\
\hline
\end{tabular}

Note: * - significant differences between groups $(p<0.05)$.

the single-component TMB containing substrate buffer R055 (Xema; Russia) to each well, incubated for 10 minutes at room temperature, and terminated the reaction by adding $100 \mu \mathrm{L}$ of $10 \% \mathrm{HCl}$ per well. Absorbance was measured at a wavelength of $450 \mathrm{~nm}$. When recording the results, the cutoff absorbance value was defined (the sum of the negative control mean absorbance and the experimentally determined coefficient), then the positivity rate was calculated for each sample, being the ratio of sample absorbance to cutoff absorbance value.

The results were interpreted based on the following criteria: the test for IgG antibodies was considered positive with the studied sample positivity rate $\geq 1.1$, and negative with the positivity rate $<0.9$. The results of the test for lgG antibodies were considered inconclusive with $0.9 \leq$ positivity rate $<1.1$. For these values, the laboratory system was validated using the reference sera. The previously characterized sera of convalescent subjects with confirmed diagnosis were used as a positive control, and the archived sera, collected in the first half of 2019, from the collection of deliberately negative sera were used as a negative control.

\section{Cells and viruses}

The VERO E6 cells (ATCC, CRL-1586) were cultured in complete DMEM medium (PanEco; Russia), supplemented with 10\% FBS (HyClone; USA), 1× GlutaMAX (Gibco; USA) and penicillin/streptomycin (100 IU/mL; $100 \mu \mathrm{g} / \mathrm{mL})$ (PanEco; Russia). SARS-CoV-2 strains PMVL-4 (GISAID EPI ISL_470898), PMVL-38 (GISAID EPI_ISL_1710856), PMVL-47 (GISAID EPI_ISL_1710865) were isolated from nasopharyngeal swabs. PMVL-38 and PMVL-47 carry mutations in the RBD domain (S477N and E484K respectively). 
Table 2. Assessment of dynamic changes in COVID-19 course severity in vaccinated and unvaccinated patients

\begin{tabular}{|c|c|c|c|c|c|c|c|}
\hline \multirow{4}{*}{$\begin{array}{l}\text { Checkpoints for severity } \\
\text { assessment (bed-days) }\end{array}$} & \multicolumn{6}{|c|}{ Patients $(n=57)$} & \multirow{4}{*}{$p$} \\
\hline & \multicolumn{3}{|c|}{ Vaccinated $n=22$} & \multicolumn{3}{|c|}{ Unvaccinated $n=35$} & \\
\hline & \multicolumn{6}{|c|}{ Disease severity evaluation (NEWS) } & \\
\hline & Mild & Moderate & Severe & Mild & Moderate & Severe & \\
\hline \multirow{2}{*}{$\begin{array}{l}\text { Upon admission to hospital } \\
\text { (checkpoint 1) }\end{array}$} & \multirow{2}{*}{$10(45.5 \%)$} & 7 & 5 & \multirow{2}{*}{$13(37.1 \%)$} & \multirow{2}{*}{$10(28.6 \%)$} & \multirow{2}{*}{$12(34.3 \%)$} & \multirow{2}{*}{$\begin{array}{l}0.699 \text { (Fischer's } \\
\text { exact test) }\end{array}$} \\
\hline & & $-31.80 \%$ & $-22.70 \%$ & & & & \\
\hline $\begin{array}{l}\text { Average bed-days } 3.5 \pm 1.2 \\
\text { (1-7 days) } \\
\text { (checkpoint 2) }\end{array}$ & $15(68.2 \%)$ & $\begin{array}{c}5 \\
-22.70 \%\end{array}$ & $\begin{array}{c}2 \\
-9.10 \%\end{array}$ & $15(42.8 \%)$ & $14(40.0 \%)$ & $\begin{array}{c}6 \\
-17.20 \%\end{array}$ & $\begin{array}{l}0.184 \text { (Fischer's } \\
\text { exact test) }\end{array}$ \\
\hline \multirow{2}{*}{$\begin{array}{l}\text { Average bed-days } \\
9.2 \pm 1.4 \\
\text { (8-12 days) } \\
\text { (checkpoint 3) }\end{array}$} & $22(100 \%)$ & 0 & 0 & \multirow[b]{2}{*}{$22(62.8 \%)$} & \multirow[b]{2}{*}{$5(14.3 \%)$} & \multirow[b]{2}{*}{$\begin{array}{c}8 \\
-22.90 \%\end{array}$} & \multirow[b]{2}{*}{$\begin{array}{l}0.002^{*} \text { (Fischer's } \\
\text { exact test) }\end{array}$} \\
\hline & \multicolumn{3}{|c|}{$\begin{array}{l}\text { All patients were discharged by day } 12 \text { of } \\
\text { hospital stay }\end{array}$} & & & & \\
\hline
\end{tabular}

\section{Assessment of the patients' sera virus} eutralization activity

The VERO E6 cells were seeded in the 96-well plate, $0.2 \times 10^{5}$ cells per well, one day before the experiment. The following day $100 \mathrm{TCID}_{50}$ of the corresponding SARS-CoV-2 variant were incubated with serial dilutions of sera for one hour at $+37^{\circ} \mathrm{C}$, and subsequently added to the 96-well plates with the Vero E6 cells. After $72 \mathrm{~h}$ the virus-induced cytopathic effect (CPE)

was asessed by MTT assay [11]. The percentage of inhibition of CPE was normalized and converted into percentage of neutralization. $\mathrm{NT}_{50}$ was calculated with the GraphPad Prism 7 software (GraphPad Software; USA).

\section{Assessment of the virus variation in the RBD region}

Total RNA was extracted from the patients' swabs and/ or SARS-CoV-2 isolates using the RIBO-prep kit (Central

Unvaccinated

Moderate

Severe
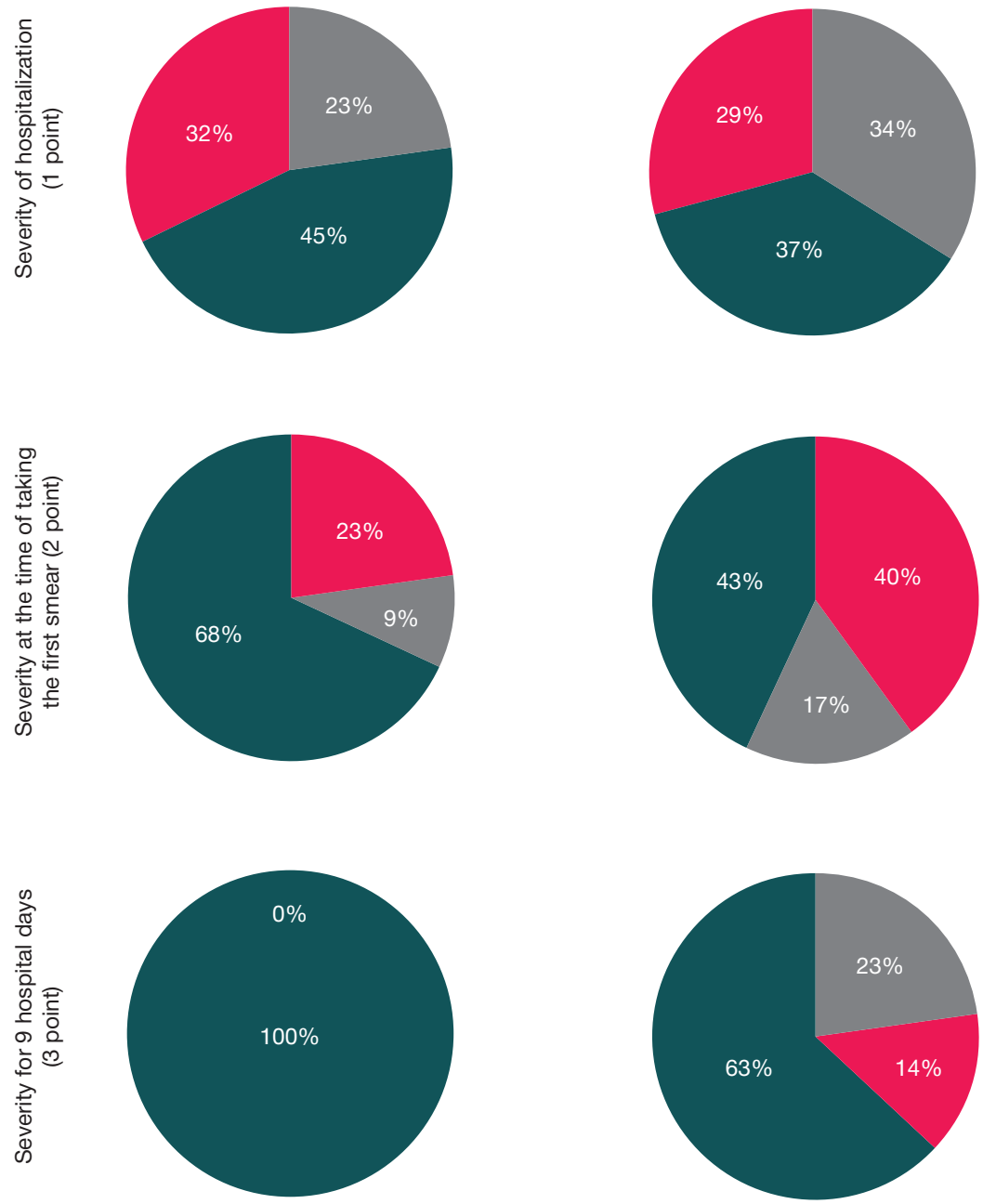

Fig. 1. Patients' distribution based on the disease severity for the assessed checkpoints (bed-days) 
Table 3. Viral load in vaccinated and unvaccinated patients

\begin{tabular}{|l|c|c|c|}
\hline \multicolumn{3}{|c|}{ Viral load, Ct } \\
\hline Groups of patients & $\mathrm{N}$ & $\mathrm{Me}\left[\mathrm{Q}_{1}-\mathrm{Q}_{3}\right]$ & \multirow{2}{*}{$\mathrm{p}$} \\
\hline Unvaccinated & 34 & $31,45[27,20-33,72]$ & \multirow{2}{*}{$0.026^{*}$ (Mann-Whitney U test) } \\
\hline Fully vaccinated & 8 & $34,78[31,41-36,48]$ & \\
\hline
\end{tabular}

Note: * - significant differences for the sample (vaccinated $n=22$, unvaccinated $n=35)(p<0.05)$.

Research Institute of Epidemiology; Russia) in accordance with the manufacturer's instructions. Amplification was performed by the one-step RT-PCR method with the use of the reaction mixture, containing (per one reaction) 10 pmol of each primer, $0.025 \mathrm{mM}$ of each dNTP (Evrogen; Russia), $5 \mu \mathrm{L}$ of $5 \mathrm{X}$ buffer $\left(100 \mathrm{mM}\right.$ Tris- $\mathrm{HCl}\left(\mathrm{pH} 8.3\right.$ at $\left.25^{\circ} \mathrm{C}\right), 150 \mathrm{mM} \mathrm{KCl}, 10 \mathrm{mM}$ $\mathrm{MgCl} 2,8 \mathrm{mM} \mathrm{DTT}), 0.25 \mu \mathrm{L}$ of M-MLV reverse transcriptase (200 U), $0.25 \mu \mathrm{L}$ of intrinsic Taq polymerase (10 U) and $10 \mu \mathrm{L}$ of RNA (about $0.5 \mu \mathrm{g}$ ). The total volume of one reaction mixture was $25 \mu \mathrm{L}$. The following olygonucleotides were selected for amplification of the SARS-CoV-2 fragment: upstream primer 5'-AACTTTAGAGTCCAACCAACAGAA-3' and downstream primer 5'-TGAAGTTGAAATTGACACATTTG-3'. Olygonucleotides make it possible to obtain the fragment of spike glycoprotein, beginning at amino acid 334 and ending at amino acid 538. Amplification was performed in the T100TM Thermal Cycler (Bio-Rad; USA). The protocol for one-step RTPCR was as follows: $50^{\circ} \mathrm{C}$ for $60 \mathrm{~min}, 95^{\circ} \mathrm{C}$ for $5 \mathrm{~min}$, then 35 cycles at $95^{\circ} \mathrm{C}$ for $15 \mathrm{~s}, 55^{\circ} \mathrm{C}$ for $10 \mathrm{~s}$, and $72{ }^{\circ} \mathrm{C}$ for $30 \mathrm{~s}$, then $72{ }^{\circ} \mathrm{C}$ for $5 \mathrm{~min}$. After amplification some of the product was applied to agarose gel, and the target fragment was detected by electrophoresis. Then the amplified products were purified to remove primers and nucleotides using the ExoSAP-IT ${ }^{\mathrm{TM}}$ PCR Product Cleanup Reagent (Thermo Fisher Scientific; USA), and the concentration was measured with the Qubit Fluorometer (Thermo Fisher Scientific; USA) in accordance with the manufacturer's instructions. Sequencing of the fragments obtained was performed with the Applied Biosystems 3500 genetic analyzer (Thermo Fisher Scientific; USA). The obtained sequences structure was analyzed using the Unipro UGENE v37.0 software.

\section{Statistical methods}

Statistical processing and plotting the curves were performed with the IBM SPSS Statistics software, version 26. Distributions were tested for normality using the Shapiro-Wilk test (when $n<50$ ) or Lilliefors corrected Kolmogorov-Smirnov test (when $n>50$ ). The significance level was defined as $p=0.05$. For distributions other than normal, the intergroup comparisons were performed with the Kruskal-Wallis test with subsequent post hoc analysis using the Mann-Whitney $U$ Test with Bonferroni correction for multiple comparisons or using the Mann-Whitney $U$ Test (for a number of groups $n=2$ ). Analysis of contingency tables was carried out using the chi-squared $\left(\chi^{2}\right)$ test or Fisher's exact test. When performing the analysis of multi-field tables, a posteriori pairwise comparisons were performed, and the multiplicity problem was solved using the Benjamini-Hochberg procedure. The impact of vaccination and the existence of mutations on the viral load was assessed by multivariate ANOVA.

\section{RESULTS}

Comparative analysis of the vaccinated and unvaccinated groups' age structure revealed no significant differences in age $(p=0.656)$. There were also no differences in the average age between groups ( $p=0.335$ (Pearson's chi-squared test)).

No significant differences in the rates of comorbidity between vaccinated and unvaccinated patients with COVID-19 were revealed: arterial hypertension - 79.0 and $72.4 \%$, cardiovascular diseases - 43.0 and $26.7 \%$, diabetes mellitus 27.0 and $16.4 \%$, obesity -47.4 and $39.6 \%$ respectively.

All the patients enrolled $(n=251)$ were hospitalized on days 1-28 after the symptom onset. There were significant differences in admission dates after the disease onset between vaccinated and unvaccinated patients: the patients, who had received at least one vaccine dose, were hospitalized significantly later $(p=0.014)$. The median time between disease onset and hospitalization was 7.5 days in vaccinated and 6 days in unvaccinated patients.

To perform clinical characterization of COVID-19, all patients ( $n=251)$ were divided based on the disease severity on the day of admission as follows: in the vaccinated group ( $n=116), 49$ (42.2 \%) patients had mild, 34 (29.3\%) had moderate, and $33(26.5 \%)$ had severe disease; in the unvaccinated group ( $n=135), 52$ (38.5\%) patients had mild, 35 (30.0\%) had moderate, and 48 (35.5\%) had severe disease. It should be emphasized that there were no significant differences in the number of patients with different disease severity within each group both in the unvaccinated group and in individuals, who had received at least one vaccine component $(p=0.498)$.

During treatment, the trend towards worsening was recognized in $2(4.5 \%)$ vaccinated patients: both patients of the 1st subgroup were transferred to ICU, and died on days 17 and 36 of hospital stay. It is important that both patients got ill during the first week (days 1 and 7) after administration of the first vaccine component, and couldn't have any protective antibodies. Two patients $(6.3 \%)$ of the $2^{\text {nd }}$ subgroup also needed intensive care management. They were provided noninvasive respiratory support. One of these patients had lymphogranulomatosis, he was transferred to the other hospital on day 10 of hospital stay with the large right gluteal hematoma spreading onto the inguinal region and pelvic retroperitoneal space, posthemorrhagic anemia. The other patient had hypertension in combination with obesity, he stayed in ICU for 32 days and was discharged from the hospital on day 56 . Both patients had not received the second vaccine component.

Table 4. Comparison of anti-RBD antibody levels in vaccinated and unvaccinated patients

\begin{tabular}{|l|c|c|c|}
\hline \multicolumn{1}{|c|}{ Groups of patients } & $n$ & positivity rate RBD \\
\cline { 3 - 4 } & & $\mathrm{Me}^{*}\left[\mathrm{Q}_{1}-\mathrm{Q}_{3}\right]$ \\
\hline Unvaccinated & 17 & $0,34[0,22-0,48]$ \\
\hline Fully vaccinated & 22 & $7,75[2,30-10,80]$ & $<0.001^{*}($ Mann-Whitney U test) \\
\hline
\end{tabular}

Note: ${ }^{*}$ - significant differences $(p<0.05)$, 
Table 5. RBD domain mutation rate in the groups being compared

\begin{tabular}{|c|c|c|}
\hline Groups of patients & No mutations in RBD domain $(n=9)$ & Mutations in RBD domain $(n=10)$ \\
\hline $\begin{array}{c}\text { Unvaccinated } \\
(n=11)\end{array}$ & $8(72.7 \%)$ & $3(27.3 \%)$ \\
\hline $\begin{array}{c}\text { Vaccinated } \\
(n=8)\end{array}$ & $1(12.5 \%)$ & $7(87.5 \%)$ \\
\hline
\end{tabular}

Note: * $-p=0.020$ (Fisher's exact test).

No deaths were observed in the $2^{\text {nd }}$ and $3^{\text {rd }}$ subgroups of vaccinated patients; in the unvaccinated group, 11 individuals needed intensive care management, 10 of them died.

The median length of hospital stay was 8 days in vaccinated patients (including those, who received single vaccine component), and 10 days in unvaccinated patients $(p<0.001)$.

In addition, to evaluate the dynamic changes throughout the clinical course of the disease, the disease severity was assessed on days 1-7 and 8-12 of hospital stay in patients, who had received both vaccine components $(n=22)$ and got ill after 14 days, compared to the group of unvaccinated patients ( $n=35)$, who got ill within the same period (Table 2; Fig. 1).

Thus, it has been shown that based on the Fisher's exact test there were no significant differences in the number of patients with different disease severity in the vaccinated and unvaccinated groups upon admission to hospital (checkpoint 1) ( $p=0.699$ ). During the first week of hospital stay (checkpoint 1 , days 1-7 of hospital stay) no significant differences were revealed as well $(p=0.184)$. However, assessment of checkpoint 3 (days 8-12 of hospital stay) showed that $100 \%$ of vaccinated patients had a mild disease; the proportion of patients with a mild disease in the unvaccinated group was significantly lower (63\%, $p=0.002$ ) (see Fig. 1). Comparative analysis of checkpoints in the studied groups based on the disease severity (with the use of Friedman test for related samples) showed that there was a significant decrease $(p<0.001)$ in the disease severity in the vaccinated group; in the unvaccinated group this trend was of borderline significance $(p=0.058)$.

The further research tactics was defined by the search for the desease severity criteria taking into account the RBD domain mutations, viral load levels and humoral immune response in the patients.

The viral load in the vaccinated and unvaccinated groups was low, however, significant viral load was lower in the group of vaccinated patients ( $p<0.05)$ (Table 3$)$.

Assessment of the humoral immune response in the studied groups showed that the lgG antibody levels were significantly $(p<0.001)$ higher in the vaccinated group compared to unvaccinated group (Table 4). Further research is needed to evaluate the duration of the protective immune response.

The spread of the virus involves introduction into the human population, high host mortality, and the ability of the virus to mutate in order to survive in biological environment.

Identification of the SARS-COV-2 RBD domain mutations in biological samples, obtained from the patients $(n=19)$, showed that the virus mutated in $\mathrm{RBD}$ region both in the vaccinated and unvaccinated groups, however, mutations occurred more frequently in the vaccinated group (Table 5; Fig. 2). The presence of mutations demonstrates the need for monitoring the disease clinical features in vaccinated patients and sequencing the virus in order to upgrade the specific preventive measures in a rapid and timely manner.

Viral load testing showed that vaccination reduced viral load in the infected individuals. It has been found that in case of the disease development, the downward trend in viral load in the samples containing the virus, carrying mutations in the RBD domain, was observed both in vaccinated and unvaccinated patients. Multivariate ANOVA revealed a significant correlation between the viral load and the fact of being vaccinated/ unvaccinated $(p<0.001)$, the variance contribution was 39.0\%. Correlation with the presence of mutations also appeared to be significant $(p=0.038)$, the variance contribution was $8.0 \%$. The relationship between vaccination and the presence of mutations was not significant $(p=0.650)$ (Fig. 3).

Differential assessment of virus neutralization activity (VNA) in sera of the patients, vaccinated with two doses of vaccine, although infected with COVID-19, was performed in order to investigate the possible mechanisms of the new virus variants evading protective antibodies in vaccinated individuals. Since there were RBD domain mutations in the majority of samples $(n=6)$, including S477N, S477N+A522S, E484K and E484K+S494P, VNA was assessed in all the samples provided in relation to the original variant of the virus, containing D614G substitution, and two variants with mutations S477N and $\mathrm{E} 484 \mathrm{~K}$, available from our collection of viral isolates.

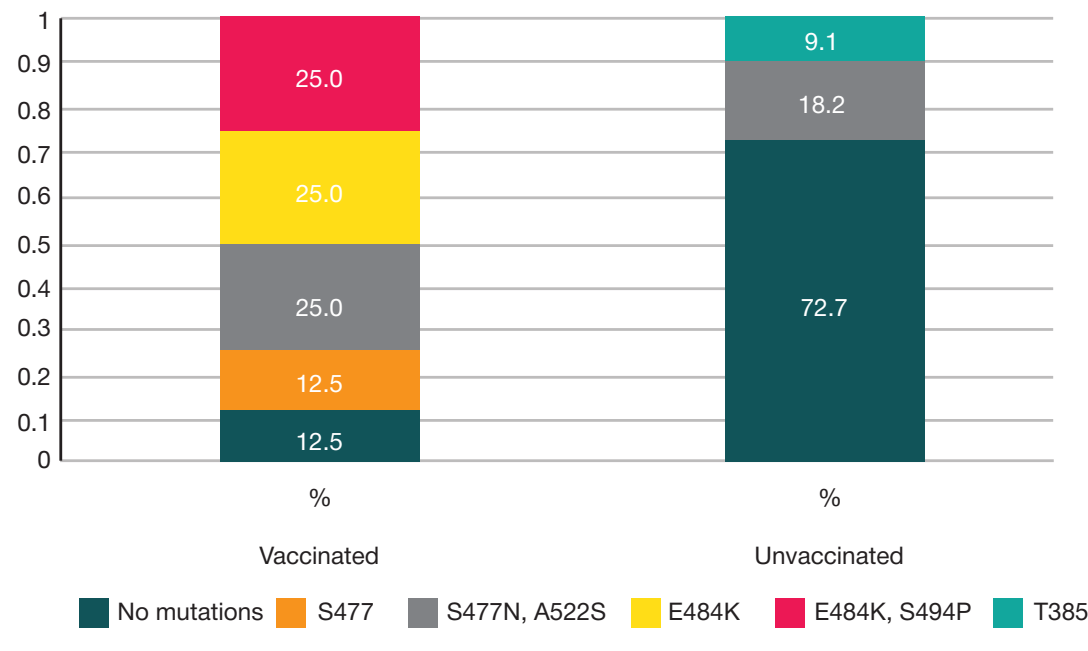

Fig. 2. Distribution of mutations in the RBD domain of SARS-CoV-2 viruses 


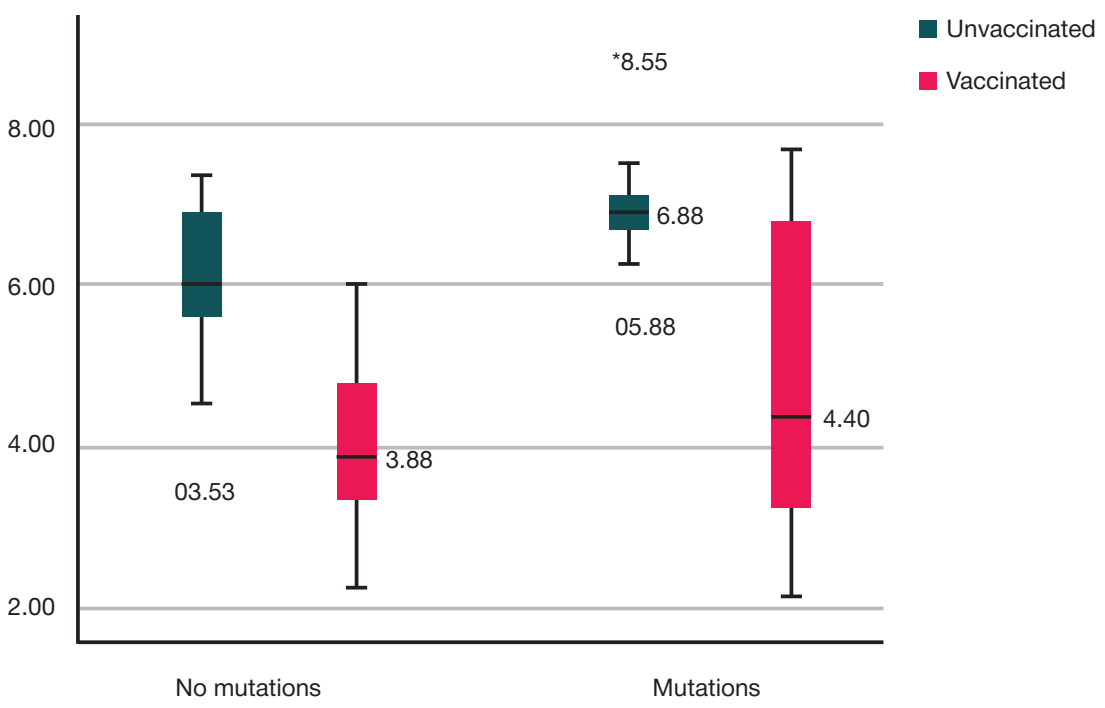

Fig. 3. Comparative assessment of viral load in biological samples of vaccinated and unvaccinated patients, carrying mutations in the RBD domain

Table 6 presents the VNA levels against different variants of SARS-CoV-2 virus mutations in the samples, obtained from the patients $(n=6)$. The neutralizing titers (NT50) were calculated using the GraphPad Prism 7 software.

Then the comparative assessment of the VNA levels against different variants of SARS-CoV-2 virus mutations was performed. Fig. 4 (upper row) demonstrates p-values with 95\% confidence interval (Wilcoxon test).

No significant differences in VNA of sera with different SARS-CoV-2 variants were revealed both when assessing all sera and when assessing single sera, obtained from the patients carrying characteristic mutations.

\section{DISCUSSION}

The results obtained show that, like any other immunobiological preparation, Sputnik V vaccine, developed and successfully used in healthcare practice as a preventive medicine, is not $100 \%$ effective, especially during the ongoing pandemic. However, the use of vaccines in such an extraordinary situation would enable to reduce both the number of patients with severe diasease and the number of deaths.

Currently, Sputnik V is successfully used in more than 67 countries around the world [12]. A total of 39,589,464 people (27.11\%) have been fully vaccinated in the Russian Federation before September 11, 2021 [13].

Consequently, studying the factors, which result in COVID-19 infection in vaccinated individuals, as well as monitoring the clinical course of the disease would provide practical healthcare and society in general with additional information on vaccination.
In this study we tried to assess the clinical and laboratory parameters in patients, vaccinated with Sputnik V, on various dates after administration of the first and second doses of vaccine compared with the group of unvaccinated patients.

Assessment of dynamic changes in COVID-19 severity in fully vaccinated individuals, who had got ill 14 days after administration of the second component, and unvaccinated patients, who had got ill within the same time period, showed that $100 \%$ of vaccinated patients had mild disease on days 8-12 of hospital stay. There were no cases of transfer to ICU or deaths in the group of fully vaccinated individuals, possessing protective immunity against SARS-CoV-2.

In addition to the clinical course severity assessment, testing by RT-PCR and real-time RT-PCR, viral RNA RBD region sequencing, differential monitoring of neutralizing antibody titers, and evaluation of IgG-response towards the S protein RBD domain were performed.

The viral load levels in the studied groups were diverse. As could be expected, the viral load in fully vaccinated patients (who had got ill 14 days after administration of the second vaccine component) was significantly $(p=0.026)$ lower compared to unvaccinated group. Reduced viral load in the group of individuals, vaccinated with Sputnik V, makes this group less contagious with high probability.

The significant level of anti-RBD IgG antibodies in the group of fully vaccinated patients exceeded the values, obtained in the unvaccinated group $(p<0.001)$. The results obtained showed that full-fledged specific immune response was formed within two weeks after administration of the booster Sputnik $V$ vaccine dose.

IgG antibody levels (positivity rate 4.72 [1.47-9.88]) in the subgroups of incompletely vaccinated individuals were rather low, which could partly explain COVID-19 infection

Table 6. Levels of virus neutralizing antibodies (VNA) against the variants of SARS-CoV-2 mutations

\begin{tabular}{|c|c|c|c|c|}
\hline \multirow{2}{*}{ № } & \multirow{2}{*}{ Sample name } & \multicolumn{3}{|c|}{ NT $_{50}$} \\
\cline { 3 - 5 } & & PMVL-4_D614G & PMVL-38_S477N & PMVL-47_E484K \\
\hline 1 & 3222_S477N & 373.8 & 452.6 & 451.9 \\
\hline 2 & 4003_S477N, A522S & 186.7 & 293.5 & 153.2 \\
\hline 3 & 4310_E484K,S494P & 452.3 & 452.6 & 451.6 \\
\hline 4 & 573_E484K,S494P & 256.2 & 202.5 & 452.6 \\
\hline 5 & 4267_E484K & 226.5 & $>640$ & $>640$ \\
\hline 6 & 4160_E484K & 65.52 & 29.26 & 320 \\
\hline
\end{tabular}



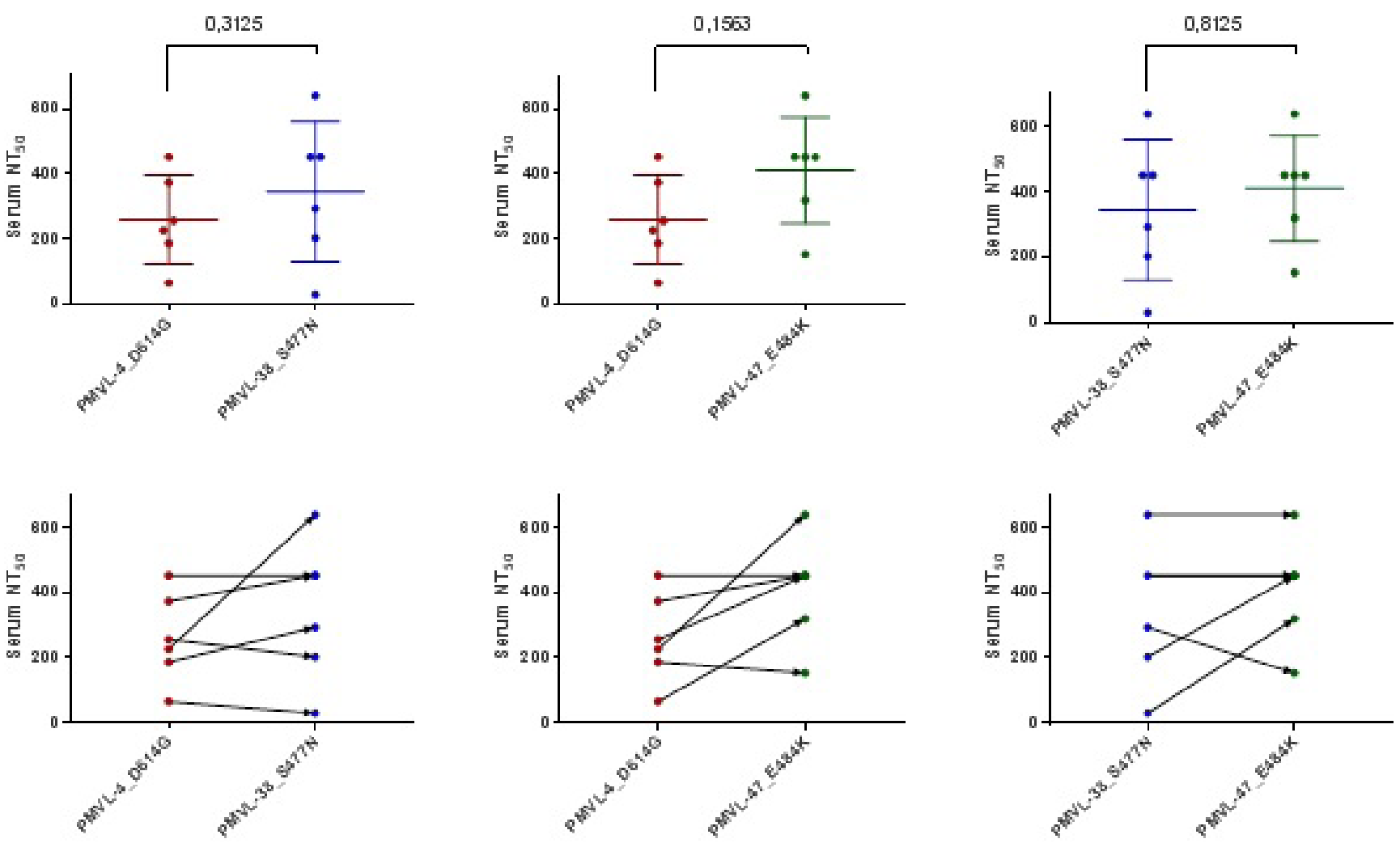

Fig. 4. Comparative assessment of the titers of neutralizing antibodies against different SARS-CoV-2 variants. * - upper row is represented by $p$-values with $95 \%$ confidence interval (Wilcoxon test)

in the enrolled vaccinated patients. Furthermore, a number of researchers point out that a significant proportion of people demonstrates insufficient specific response to infection, which is probably due to insufficient B cell maturation [14].

Assessment of the virus mutations in RBD region, performed in the limited number of biological samples, showed that mutations in RBD domain occurred both in vaccinated and unvaccinated patients. Mutations were more frequent in the vaccinated group. However, it should be recalled that vaccination itself has no effect on mutations or mutation rate, which provides the basis for preventive vaccination.

Experimental design showed no apparent differences in VNA of antibodies in the studied patients. No significant differences in VNA of sera with different SARS-CoV-2 variants were revealed both when assessing all sera and when assessing single sera, obtained from the patients carrying characteristic mutations. It is worth noting that the average VNA against the viruses carrying mutations was a little higher compared to VNA against the wild-type virus. However, a significant decline in the neutralizing activity of antibodies and sera against the chimeric SARS-CoV-2 strains or isogenic variants containing mutations [15].

Research findings point to protective properties of Sputnik V. The fully vaccinated individuals are at lower risk of COVID-19 infection compared to unvaccinated individuals, especially in the context of the ongoing pandemic. The data on the vaccine assessment, obtained by foreign researches, are in line with our data [2].
A major limitation of this study is the small sample of fully vaccinated patients, not allowing to assess fully the impact of rare virus mutations on the clinical course of the disease. It is unclear to what extent the new variants of the virus mutations can differentially lead to infection in vaccinated individuals compared to unvaccinated individuals within the same population. This study involves observation during the specific time period in the Moscow Region, which is characterized by the presence of specific regional mutations in strains.

\section{CONCLUSIONS}

The patients vaccinated with two components of Sputnik V vaccine, who had got ill, had a mild disease (100\%), they were discharged from the hospital on days 8-12 of hospital stay. There were no deaths in the group of fully vaccinated patients. The viral load in fully vaccinated patients was significantly lowed compared to the unvaccinated group. Mutations within the RBD domain were observed in the groups of both vaccinated and unvaccinated patients. Significant levels of anti-RBD IgG antibodies were observed in the group of vaccinated individuals compared to unvaccinated individuals. Duration of the pandemic, mutations of the virus, altered structure of circulating strains, assessment of clinical features in vaccinated and infected individuals require a more detailed and objective analysis.

\section{References}

1. Kolobukhina LV, Burgasova OA, Kraeva LA, Gushchin VA, Burtseva El, Kruzhkova IS, et al. Clinical and laboratory profile of patients with COVID-19 hospitalized in an infectious hospital in Moscow in the period from May to July 2020. Infectious diseases.
2021; 19 (2): 5-15. Russian.

2. Rzymski P, Pazgan-Simon M, Krzysztof Simon T, ZarębskaMichaluk D, Szczepańska B, et al. Clinical Characteristics of Hospitalized COVID-19 Patients Who Received at Least One 
Dose of COVID-19 Vaccine. 2021; 9 (7): 78. Available from: https://www.mdpi.com/2076-393X/9/7/781

3. Logunov DY, Dolzhikova IV, Shcheblyakov DV, Tukhvatulin Al, Zubkova OV, Dzharullaeva AS, et al. Safety and efficacy of an RAD26 and RAD5 vector-based heterologous prime-boost COVID-19 vaccine: an interim analysis of a randomised controlled phase 3 trial in Russia. The Lancet. 2021; 397 (10275): 671.

4. Statistics and Research Coronavirus (COVID-19) Vaccinations. Available from: https://ourworldindata.org/covid-vaccinations.

5. Dong E, Du H, Gardner L. An interactive web-based dashboard to track COVID-19 in real time. Lancet Infect Dis. 2020; 20 (5): 5334. DOI: 10.1016/S1473-3099(20)30120-1. Erratum in: Lancet Infect Dis. 2020 Sep; 20 (9): e215.

6. Haas EJ, Angulo FJ, McLaughlin JM, Anis E, Singer SR, Khan F, et al. Impact and effectiveness of mRNA BNT162b2 vaccine against SARS-CoV-2 infections and COVID-19 cases, hospitalisations, and deaths following a nationwide vaccination campaign in Israel: an observational study using national surveillance data. Lancet. 2021; 397 (10287): 1819-829. DOI: 10.1016/S01406736(21)00947-8.

7. Hodick G, Tene L, Rotem RS, Patalon T, Gazit S, Ben-Tov A, et al. The effectiveness of the TWO-DOSE BNT162b2 vaccine: analysis of real-world data. Clin Infect Dis. 2021; ciab438. DOI: 10.1093/ cid/ciab438. Epub ahead of print. PMID: 33999127.

8. Logunov DY, Dolzhikova IV, Zubkova OV, Tukhvatullin AI, Shcheblyakov DV, Dzharullaeva AS, et al. Safety and immunogenicity of an rAd26 and rAd5 vector-based heterologous prime-boost COVID-19 vaccine in two formulations: two open, non-randomised phase $1 / 2$ studies from Russia. The Lancet. 2020; 396 (10255): 887-97.

9. Keehner J, et al. SARS-CoV-2 Infection after Vaccination in Health Care Workers in California. N Engl J Med. 2021; 384: 1774-5. DOI: 10.1056/NEJMc2101927.

10. NEWS (or NEWS2) score when assessing possible COVID-19 patients in primary care. Available from: https://www.cebm. net/covid-19/should-we-use-the-news-or-news2-score-whenassessing-patients-with-possible-covid-19-in-primary-care/.

11. Amanat F, White KM, Miorin L, Strohmeier S, McMahon M, Meade P, et al. An In Vitro Microneutralization Assay for SARS-CoV-2 Serology and Drug Screening. Curr Protoc Microbiol. 2020; 58 (1): e108. DOI: 10.1002/cpmc.108.

12. V kakih stranah vakcina "Sputnik V" odobrena k primeneniju. Dostupno po ssylke: https://sputnik-meedia.ee/ infographics/20210607/573214/V-kakikh-stranakh-vaktsinaSputnik-V-odobrena-k-primeneniyu.html. Russian.

13. Statistika vakcinacii ot koronavirusa (COVID-19) $\vee$ Rossii. Dostupno po ssylke: https://index.minfin.com.ua/reference/ coronavirus/vaccination/russia/. Russian.

14. Schmidt F, Weisblum Y, Muecksch F, et al. Measuring SARS-CoV-2 neutralizing antibody activity using pseudotyped and chimeric viruses. J Exp Med. 2020; 217 (11): e20201181-e20201181.

15. Diamond M, Chen R, Xie X, Case J, Zhang X, VanBlargan L, et al. SARS-CoV-2 variants show resistance to neutralization by many monoclonal and serum-derived polyclonal antibodies. Res Sq. 2021; 3: 228079. DOI: 10.21203/rs.3.rs-228079/v1. Preprint.

\section{Литература}

1. Колобухина Л. В., Бургасова О. А., Краева Л.А, Гущин В. А., Бурцева Е. И., Кружкова И. С. и др. Клинико-лабораторный профиль пациентов с COVID-19, госпитализированных в инсекционный стационар г. Москвы в период с мая по июль 2020 года. Инфекционные болезни. 2021; 19 (2): 5-15.

2. Rzymski P, Pazgan-Simon M, Krzysztof Simon T, ZarębskaMichaluk D, Szczepańska B, et al. Clinical Characteristics of Hospitalized COVID-19 Patients Who Received at Least One Dose of COVID-19 Vaccine. 2021; 9 (7): 78. Available from: https://www.mdpi.com/2076-393X/9/7/781.

3. Logunov DY, Dolzhikova IV, Shcheblyakov DV, Tukhvatulin AI, Zubkova OV, Dzharullaeva AS, et al. Safety and efficacy of an RAD26 and RAD5 vector-based heterologous prime-boost COVID-19 vaccine: an interim analysis of a randomised controlled phase 3 trial in Russia. The Lancet. 2021; 397 (10275): 671.

4. Statistics and Research Coronavirus (COVID-19) Vaccinations. Available from: https://ourworldindata.org/covid-vaccinations.

5. Dong E, Du H, Gardner L. An interactive web-based dashboard to track COVID-19 in real time. Lancet Infect Dis. 2020; 20 (5): 5334. DOI: 10.1016/S1473-3099(20)30120-1. Erratum in: Lancet Infect Dis. 2020 Sep; 20 (9): e215.

6. Haas EJ, Angulo FJ, McLaughlin JM, Anis E, Singer SR, Khan F, et al. Impact and effectiveness of mRNA BNT162b2 vaccine against SARS-CoV-2 infections and COVID-19 cases, hospitalisations, and deaths following a nationwide vaccination campaign in Israel: an observational study using national surveillance data. Lancet. 2021; 397 (10287): 1819-829. DOI: 10.1016/S01406736(21)00947-8.

7. Hodick G, Tene L, Rotem RS, Patalon T, Gazit S, Ben-Tov A, et al. The effectiveness of the TWO-DOSE BNT162b2 vaccine: analysis of real-world data. Clin Infect Dis. 2021; ciab438. DOI: 10.1093/ cid/ciab438. Epub ahead of print. PMID: 33999127.
8. Logunov DY, Dolzhikova IV, Zubkova OV, Tukhvatullin Al, Shcheblyakov DV, Dzharullaeva AS, et al. Safety and immunogenicity of an rAd26 and rAd5 vector-based heterologous prime-boost COVID-19 vaccine in two formulations: two open, non-randomised phase 1/2 studies from Russia. The Lancet. 2020; 396 (10255): 887-97.

9. Keehner J, et al. SARS-CoV-2 Infection after Vaccination in Health Care Workers in California. N Engl J Med. 2021; 384: 1774-5. DOI: 10.1056/NEJMc2101927.

10. NEWS (or NEWS2) score when assessing possible COVID-19 patients in primary care. Available from: https://www.cebm. net/covid-19/should-we-use-the-news-or-news2-score-whenassessing-patients-with-possible-covid-19-in-primary-care/.

11. Amanat F, White KM, Miorin L, Strohmeier S, McMahon M, Meade $\mathrm{P}$, et al. An In Vitro Microneutralization Assay for SARS-CoV-2 Serology and Drug Screening. Curr Protoc Microbiol. 2020; 58 (1): e108. DOI: 10.1002/cpmc.108.

12. В каких странах вакцина "Спутник V" одобрена к применению. Доступно по ссылке: https://sputnik-meedia. ee/infographics/20210607/573214/V-kakikh-stranakh-vaktsinaSputnik-V-odobrena-k-primeneniyu.html.

13. Статистика вакцинации от коронавируса (COVID-19) в России. Доступно по ссылке: https://index.minfin.com.ua/ reference/coronavirus/vaccination/russia/.

14. Schmidt F, Weisblum Y, Muecksch F, et al. Measuring SARS-CoV-2 neutralizing antibody activity using pseudotyped and chimeric viruses. J Exp Med. 2020; 217 (11): e20201181-e20201181.

15. Diamond $\mathrm{M}$, Chen $\mathrm{R}$, Xie X, Case J, Zhang X, VanBlargan L, et al. SARS-CoV-2 variants show resistance to neutralization by many monoclonal and serum-derived polyclonal antibodies. Res Sq. 2021; 3: 228079. DOI: 10.21203/rs.3.rs-228079/v1. Preprint. 